\title{
Redaksioneel
}

\section{Navorsingsbeleid sonder navorsingskultuur}

Dit is ' $n$ gemeenplaas om te sê dat die Suid-Afrikaanse volkshuishouding in die oorgangstydperk wat ons tans beleef voor groot uitdagings gestel word. Dit is wel belangrik om te besef dat vele van die uitgangspunte vir toekomstige beleid wat tans in die denke van besluitnemers gevestig word, ' $n$ standhoudende invloed in die toekoms gaan hê. Op die lang termyn gaan een van die belangrikste van hierdie beleidsake vir die toekoms die een oor ' $n$ navorsingsbeleid wees, en hierby word ingesluit ' $n$ navorsingsbeleid vir die natuurwetenskappe, tegnologie, asook die geesteswetenskappe.

Tans het die staat klaarblyklik geen deurdagte of duidelik omskrewe navorsingsbeleid nie. Uit toesprake en stellings deur senior politici, staatsamptenare en ander besluitnemers word die algemene denke en persepsies oor navorsing egter wel duidelik. Dit lui min of meer as volg: Suid-Afrika se grootste en akuutste probleme is die vinnige aanwas van sy bevolking en die ongelyke verdeling van rykdom, wat grotendeels saamval met ras. Altwee hierdie probleme kan slegs deur sterk en volgehoue ekonomiese groei sinvol opgelos word. As daar gekyk word na daardie lande wat die afgelope dertig jaar die beste ekonomiese groei gehandhaaf het, dan is dit nie lande wat ryk bedeel is met grondstowwe nie, maar lande wat hulle toegespits het op tegnologiese vooruitgang en vernuf, lande soos Japan, Taiwan, Singapoer en so meer. Die logiese gevolgtrekking is dus dat Suid-Afrika hierdie voorbeeld moet volg en sy ekonomiese groei moet koppel aan' $n$ toename in die ontwikkeling van vervaardigde goedere met ' $n$ hoëtegnologie-inhoud. Aangesien die staat se fondse tans uiters beperk is, ook vir navorsing, sal die bestaande begroting vir navorsing toenemend aangewend moet word vir tegnologiese navorsing, liefs markgerig, en met die einddoel om meetbare, tasbare produkte te lewer. Navorsing wat ' $n$ verbreding van basiese kennis teweegbring en wat kultuurprodukte skep, word binne hierdie denke geduld, maar oor die algemeen tog beskou as 'n luukse wat ' $n$ arm land wat in 'n oorlewingstryd gewikkel is, eintlik nie kan bekostig nie. ' $n$ Beleid wat op hierdie aannames berus en wat hierdie vertrekpunte gebruik, is logies, konsekwent en 'n tipiese voorbeeld van vertikale denke. In baie opsigte is dit egter kortsigtig, beperkend en verskraal dit die intellektuele basis waarop Suid-Afrika die 21 ste eeu betree.

'n Groot aantal waarskuwingsliggies begin flikker wanneer so ' $n$ logiese, harde, tegnologiegerigte navorsingsbeleid konsekwent en nougeset toegepas word. Die geskiedenis van die wetenskap toon duidelik dat die moeder van tegnologiese deurbrake sonder uitsondering fundamentele navorsing was. Ondersoeke na die aard van tegnologiese deurbrake toon ook duidelik dat die motivering by die persone daarby betrokke byna sonder uitsondering intellektuele nuuskierigheid was en nié onmiddellike finansiële gewin nie. Dit blyk ook uit tendense aan Suid-Afrikaanse universiteite dat, nieteenstaande voortdurende openbare oproepe om meer tegnologiegerigte natuurwetenskaplikes, studente hulle toenemend in ander rigtings bekwaam. Dit wil dus voorkom of die huidige denke oor navorsingsbeleid nie voldoende kennis neem van navorsing as ' $n$ intellektuele kultuuropdrag nie. Dit wil ook voorkom of die persoonlike behoefte van individuele navorsers aan erkenning, aan 'n intellektueel stimulerende omgewing en aan die geleentheid om probleme na te vors waarheen dit ookal mag lei, of al hierdie "sagte" beleidsaspekte, grotendeels oor die hoof gesien word.

Dit is belangrik dat daar in hierdie oorgangstydperk in Suid-Afrika 'n navorsingskultuur gevestig en uitgebou word - aan universiteite, by besluitnemers, by die media en by die publiek. So 'n navorsingskultuur moet die onderliggende uitgangspunt insluit dat navorsing in sy wese' $n$ kultuuropdrag is, dat dit die mens wat daarmee besig is, verryk, en dat dit die lewenskwaliteit van die nasie waarin dit beoefen word, ophef. Dit behoort nou deel van besluitnemers se visie gemaak te word dat basiese navorsing nie 'n Eerstewêreldluukse is nie, maar'n essensiële deel van die kultuurmondering van enige land - iets wat ons met trots behoort te koester. In hierdie oorgangstydperk wat ons beleef, gaan daar aan ons universiteite' $n$ toename wees in studente wat uit agtergeblewe gemeenskappe kom. Dit is van kardinale belang dat hierdie studente as veelsydige, afgeronde en opgevoede mense die universiteite sal verlaat, met 'n goeie begrip van die rykdom van die Westerse kultuur. Baie van dié studente kom uit 'n omgewing waar daar geen of weinig waardering is vir die lewe van die intellek. Dit is daarom belangrik dat hierdie studente ' $n$ liefde vir navorsing as kultuurarbeid bygebring word. Dit is ook belangrik dat die groeiende getal besluitnemers uit ons Derdewêreldgemeenskappe toenemend bewus gemaak word van die rol van navorsing in die breë kulturele en intellektuele lewe van 'n nasie.

'n Navorsingsbeleid wat nie stewig rus op 'n diepgewortelde navorsingskultuur nie, is hoogs waarskynlik op die langer termyn tot mislukking gedoem. Dit is belangrik dat alle besluitnemers sal besef dat ons nie die tegnologiese vrugte van die navorsingsboom sal kan pluk as ons nie die kultuurwortels van hierdie boom voed en versorg nie. 